\title{
FORECASTING TARIFFS FOR THE DAY-AHEAD MARKET BASED ON THE ADDITIVE MODEL
}

\author{
E.A. Lyaskovskaya ${ }^{1}$, P.K. Zarjitskaya-Thierling ${ }^{2}$, O.A. Dmitrina ${ }^{3}$ \\ ${ }^{1}$ South Ural State University, Chelyabinsk, Russian Federation \\ ${ }^{2}$ Darmstadt Clinic, Darmstadt, Germany \\ ${ }^{3}$ LLC "Indirect", Chelyabinsk, Russian Federation \\ E-mails: liaskovskaiaea@susu.ru,zarjitskaya-thierling@mail.klinikum-darmstadt.de, \\ dmitrina.oa@mail.ru
}

\begin{abstract}
The problem of constructing an additive model for forecasting of the market tariff for the day ahead is solved. The trend component is constructed on the basis of the autoregressive model of already known values of the day-ahead market tariff and the external factor of electricity consumption according to the United Energy System (UES) of the Urals Wholesale Electricity and Power Market (OREM) of Russia for 2009-2018. Based on the construction of the autocorrelation function, three seasonal components are identified in the time series of hourly values of the market tariff for the day ahead: annual (8760 values), weekly (168 values), daily (24 values). A harmonic model of each component is constructed. The final additive model is constructed taking into account the specifics of the electricity market and the process of setting the market tariff for the day ahead and a balancing market. The practical significance of the developed additive model is adequate accuracy with the well-known models for forecasting of the market tariff for the day ahead of the UES of the Urals. The proposed model allows the subjects of the electric power industry to avoid penalties from the balancing market by ensuring high accuracy of forecasting.

Keywords: modelling; forecasting; autoregression; additive model; electric power industry; energy market.
\end{abstract}

\section{Introduction}

The fuel and energy complex of Russia has always played an important role in the country's economy. During the years of reform, in connection with a sharp drop in production in other sectors of the economy, its role has increased even more. There was a wide variety of approaches to the theoretical understanding of the existing models of energy markets in the country and the calculation of their output parameters [1]. The practical significance of such studies, especially in terms of price forecasts and estimates of prospective energy consumption, is high for both producers and consumers of energy. In the context of liberalization of the Russian wholesale electricity market, it becomes especially important for energy companies to forecast prices and consumption levels, as well as to formulate an optimal behavior strategy on the wholesale market. Companies are forced to operate under conditions of high uncertainty [2]. In this situation, the competitive advantage for market participants is the use of highly effective systems for forecasting of prices and volumes of energy consumption, the formation of a cost management strategy. Under these conditions, development of appropriate scientific and methodological mechanisms is particularly relevant. 


\section{Analysis of the Hour Values of the Market Tariff for the Day Forward of the Ural UES}

The hourly rate data of the day-ahead market (DAM) can be attributed to the time series, because indicators are numerical, ordered in time and characterize the levels of the cost of electricity consumed at successive points in time. A graph of the dynamics of the market tariff for the day ahead is presented in Fig. 1.

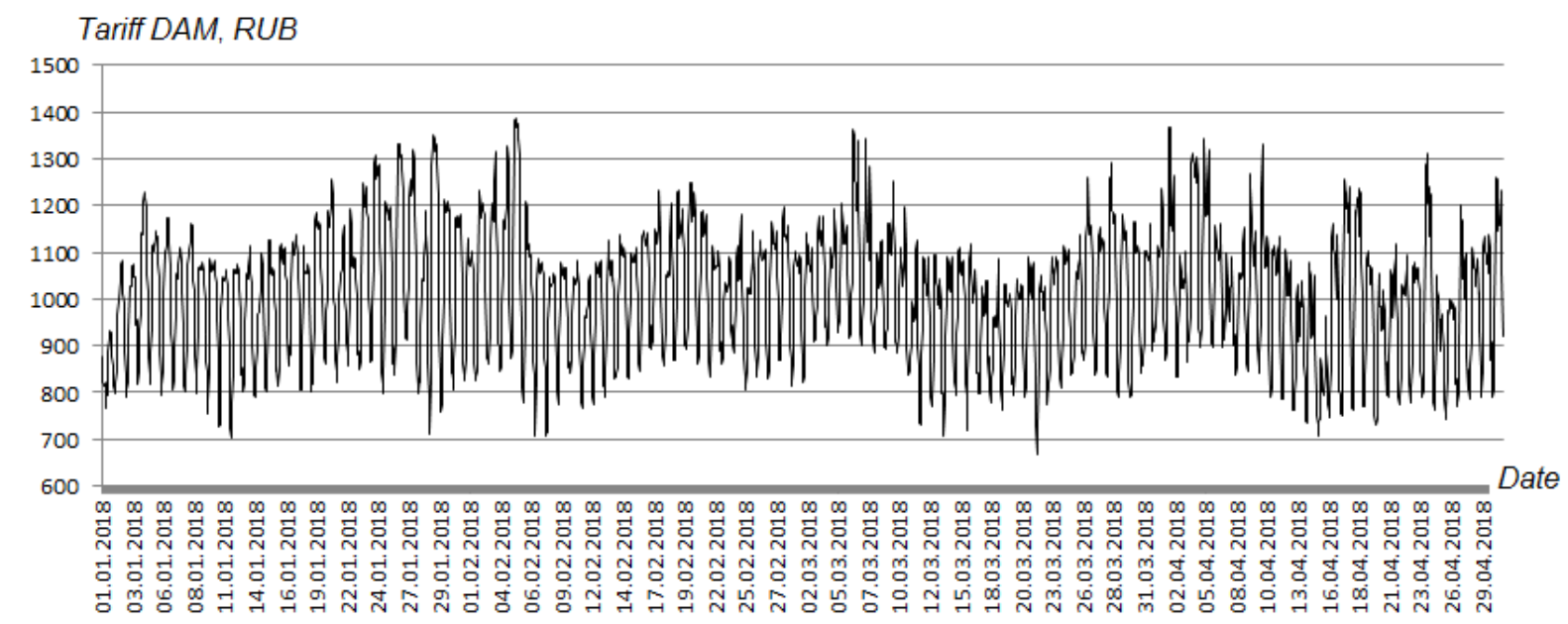

Fig. 1. DAM tariff hourly values according to PJSC Chelyabenergosbyt from January to April 2018

The first component of the additive model is the trend component. The Foster-Stuart method confirms the presence of a trend in the time series of hourly data of the DAM tariff, because $t_{p}=109,5$, which is more than the tabular value $t_{0,95 ; 2556}=1,96$. To determine the degree of a polynomial that describes a trend, a method for determining the presence of a trend in series of successive differences is used. In the framework of the study for the presence of trends, successive differences up to 6 orders were found [3, 4]. The trend disappears in the fourth-order time series, but when constructing the fourth-order linear trend equation, the coefficients for the variables $x^{4}, x^{3}$ are not statistically significant, similar to the situation in the third-order linear trend equation, therefore, despite the increase in the determination coefficient with an increase in the degree of the polynomial, it is advisable to use the second-order polynomial of the form

$$
y_{t}=-3 \cdot 10^{-5} \cdot x^{2}+0,0249 \cdot x+1026,5 .
$$

The linear equation of second-order polynomial (1) is taken as a trend component of the additive model of the series under study.

Autocorrelation coefficients reflect the degree of tightness of the relationship between the levels of the original time series and the levels of the series shifted back one or more time intervals. According to the autocorrelation function, the autocorrelation coefficient with the lag equal to 1 is significant [5]. In the model, we introduce the autoregressive component of the first order instead of the second-order polynomial, for which we construct the autoregression equation

$$
y_{t}=53,61+0,947 \cdot y_{t-1} .
$$


In order to submit an auction application to the System Operator of the Unified Energy System (SO UES) of Russia, it is necessary to take into account the market tariff and the amount of electricity consumed. To forecast the tariff of DAM, the consumed amount of electricity is introduced as an external factor. The correlation coefficient between the DAM tariff and the hourly volume of electricity consumption is 0,471 .

As part of the study, it is proposed to introduce the previous one into the model as an external factor, i.e. the already known value of electricity consumption. Therefore, we obtain the following equation of pairwise regression of dependence of the DAM tariff on the already known value of the volume of electricity consumption:

$$
y_{t}=504,6+0,0043 \cdot x_{t-1} .
$$

The second component of the additive model is the seasonal or vibrational component. According to autocorrelation study, the following conclusions can be drawn.

1. The first-order autocorrelation coefficient turned out to be the highest, which confirms the presence of a trend in the time series.

2. The autocorrelation coefficient for $\tau=(24 ; 48 ; 72)$ turned out to be slightly different from the first-order autocorrelation coefficient; therefore, the time series of the DAM tariff contains cyclic fluctuations with the period equal to 1 day.

3. In addition to diurnal fluctuations, there is a cyclic component with the lag equal to 7 days (168 values).

4. When constructing the autocorrelation function for the time series of hourly DAM tariff values with the range of values from 2009 to 2018, an oscillatory process with the lag equal to 1 year (8760 series levels) is revealed.

The mentioned features indicate periodicity and presence of the harmonic component of the time series.

In the course of study of the time series of the hourly values of the DAM tariff, we identify and include in the model the following 3 oscillatory processes.

Daily component is as follows:

$$
y_{t}=957,38+166,09 \cdot \cos \left(t \cdot \frac{2 \pi}{24}\right)-7,14 \cdot \sin \left(t \cdot \frac{2 \pi}{24}\right) .
$$

Weekly component is as follows:

$$
y_{t}=957,38+20,16 \cdot \cos \left(t \cdot \frac{2 \pi}{168}\right)-6,29 \cdot \sin \left(t \cdot \frac{2 \pi}{168}\right) .
$$

Annual component is as follows:

$$
y_{t}=957,38+30,88 \cdot \cos \left(t \cdot \frac{2 \pi}{8760}\right)-45,92 \cdot \sin \left(t \cdot \frac{2 \pi}{8760}\right) \text {. }
$$

\section{Construction of an Additive Forecasting Model}

Combining the obtained models of seasonal components, we obtain

$$
\begin{aligned}
y_{t}= & 957,38+166,09 \cdot \cos \left(t \cdot \frac{2 \pi}{24}\right)-7,14 \cdot \sin \left(t \cdot \frac{2 \pi}{24}\right)+20,16 \cdot \cos \left(t \cdot \frac{2 \pi}{168}\right)- \\
& -6,29 \cdot \sin \left(t \cdot \frac{2 \pi}{168}\right)+30,88 \cdot \cos \left(t \cdot \frac{2 \pi}{8760}\right)-45,92 \cdot \sin \left(t \cdot \frac{2 \pi}{8760}\right) .
\end{aligned}
$$


The average approximation error of the constructed model is 6,29\%. Replacing a fixed value by the previously found trend component control in the model equation, we reduce the approximation error to $6,01 \%$.

When combining the equations of seasonal components and first-order autoregression, we obtain

$$
\begin{aligned}
y_{t}=53,61+ & 0,947 \cdot y_{t-1}+166,09 \cdot \cos \left(t \cdot \frac{2 \pi}{24}\right)-7,14 \cdot \sin \left(t \cdot \frac{2 \pi}{24}\right)+ \\
& +20,16 \cdot \cos \left(t \cdot \frac{2 \pi}{168}\right)-6,29 \cdot \sin \left(t \cdot \frac{2 \pi}{168}\right)+ \\
& +30,88 \cdot \cos \left(t \cdot \frac{2 \pi}{8760}\right)-45,92 \cdot \sin \left(t \cdot \frac{2 \pi}{8760}\right)
\end{aligned}
$$

The approximation error increases to $7,54 \%$. The introduction of the autoregressive component into the model do not lead to positive results in the field of increasing the accuracy of forecasting of the DAM tariff. The combination of the seasonal variation model and pairwise regression increases the coefficient of determination from 0,18 to 0,84 . The equation of the model takes the form:

$$
\begin{aligned}
y_{t}=504,6+ & 0,0043 \cdot x_{t-1}+166,09 \cdot \cos \left(t \cdot \frac{2 \pi}{24}\right)-7,14 \cdot \sin \left(t \cdot \frac{2 \pi}{24}\right)+ \\
& +20,16 \cdot \cos \left(t \cdot \frac{2 \pi}{168}\right)-6,29 \cdot \sin \left(t \cdot \frac{2 \pi}{168}\right)+ \\
& +30,88 \cdot \cos \left(t \cdot \frac{2 \pi}{8760}\right)-45,92 \cdot \sin \left(t \cdot \frac{2 \pi}{8760}\right) .
\end{aligned}
$$

The combination of the autoregressive, paired regression, and vibrational components leads to the following model of the DAM tariff:

$$
\begin{gathered}
y_{t}=204,6+0,947 \cdot y_{t-1}+0,0043 \cdot x_{t-1}+166,09 \cdot \cos \left(t \cdot \frac{2 \pi}{24}\right)- \\
-7,14 \cdot \sin \left(t \cdot \frac{2 \pi}{24}\right)+20,16 \cdot \cos \left(t \cdot \frac{2 \pi}{168}\right)-6,29 \cdot \sin \left(t \cdot \frac{2 \pi}{168}\right)+ \\
+30,88 \cdot \cos \left(t \cdot \frac{2 \pi}{8760}\right)-45,92 \cdot \sin \left(t \cdot \frac{2 \pi}{8760}\right)
\end{gathered}
$$

A graphical interpretation of the model is presented in Fig. 2.

The resulting model is statistically significant, has the coefficient of determination equal to 0,89 and the approximation error equal to $3,98 \%$, which is a satisfactory indicator among the forecast models of the DAM tariff. Checking the model for adequacy shows that the remains of the model are random and distributed according to the normal law, have a zero mean value and are independent of each other.

\section{Conclusions}

1. The developed methodological approach to forecasting of the DAM tariff will help participants in the Russian wholesale electricity market to reduce significantly the risks of entering the balancing market and thereby obtain financial savings when selling and / or purchasing electricity. The constructed additive model for forecasting of the 


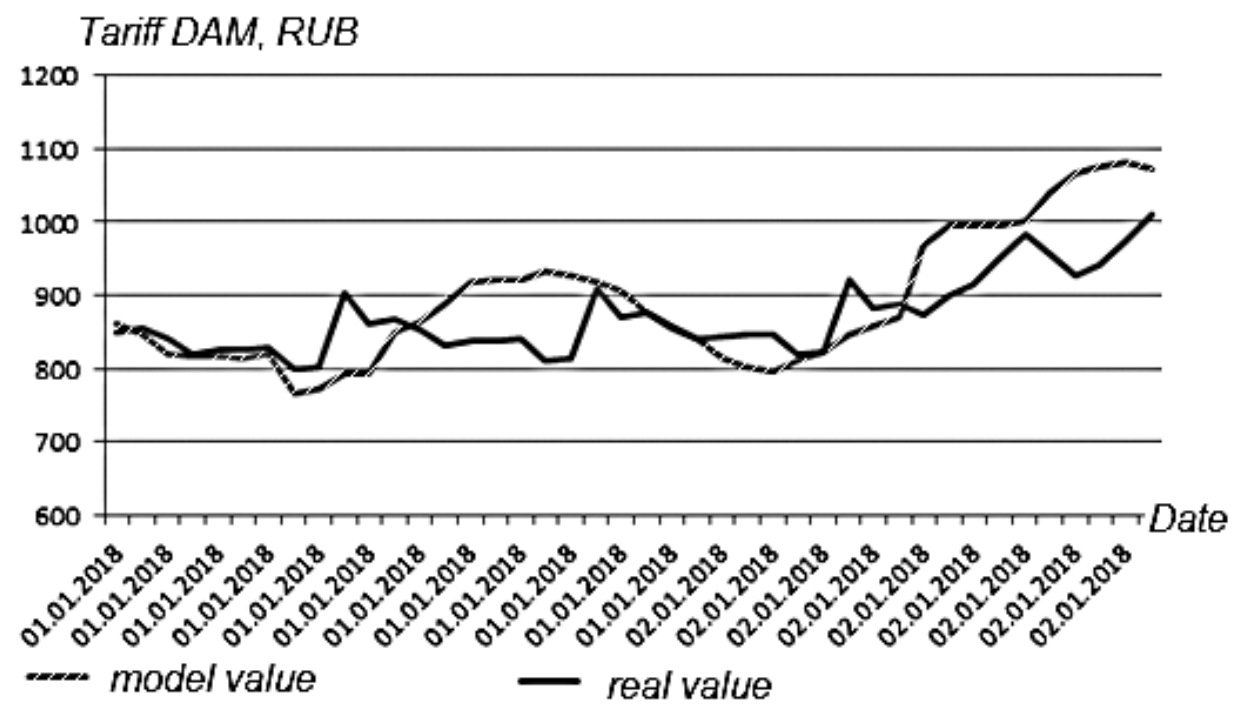

Fig. 2. DAM model with three seasonal components

hourly values of the DAM tariff takes into account the specifics of the Russian wholesale electricity market, has a low approximation error comparable to the analogs, and contains three seasonal components identified on the basis of the autocorrelation function. The autoregressive function of the hourly values of the DAM tariff with the lag equal to 1 and the external factor in the volume of electricity consumption act as a trend component. The choice of the trend component is determined by the high value of the coefficient of determination.

2. The resulting mathematical tools are recommended for use in the operational activities of the electric power industry. Based on the proposed tools, it is possible to formulate an optimal behavior strategy that ensures lower energy costs and increases energy efficiency during operations in the competitive segment of the spot energy market.

The authors congratulate Doctor of Economics, Professor V. Mokhov on the 70th birthday and express their gratitude to him for setting the problem and consultation.

\section{References}

1. Garcia R.C. Forecasting Model to Predict Day-Ahead Electricity Prices. IEEE Transactions on Power Systems, 2005, vol. 20, no. 2, pp. 867-874. DOI: 10.1109/TPWRS.2005.846044

2. Mokhov V.G., Demyanenko T.S. The Construction of the Trend Component of the Additive Model of Long-Term Forecasting of the Wholesale Market of Electric Energy and Power of Russia Using the Example of the Ural Energy System. Bulletin of the South Ural State University. Series: Economics and Management, 2018, vol. 12, no. 2, pp. 80-87. DOI: $10.14529 / \mathrm{em} 180209$

3. Taylor J.W., McSharry P.E. Short-Term Load Forecasting Methods: an Evaluation Based on European Data. IEEE Transactions on Power Systems, 2008, vol. 22, pp. 2213-2219. DOI: $10.1109 /$ TPWRS.2007.907583

4. Taylor J.W., Short-Term Electricity Demand Forecasting Using Double Seasonal Exponential Smoothing Journal of Operational Research Society, 2003, vol. 54, pp. 799-805. DOI: 10.1057 /palgrave.jors.2601589 
5. Perez, M. Time Series Analysis with Matlab. ARIMA and ARIMAX Models. Scotts Valley, CreateSpace Independent Publishing Platform, 2016.

Received March 6, 2020

УДК $330.322 .013+001.895$

DOI: $10.14529 / \mathrm{mmp} 200307$

\title{
ПРОГНОЗИРОВАНИЕ ТАРИФОВ РЫНКА НА СУТКИ ВПЕРЕД НА ОСНОВЕ АДДИТИВНОЙ МОДЕЛИ
}

\author{
Е.А. Лясковская ${ }^{1}$ П.К. Заржитская-Тирлине ${ }^{2}$, О.А. Дмитрина \\ ${ }^{1}$ Южно-Уральский государственный университет, г. Челябинск, \\ Российская Федерация \\ ${ }^{2}$ Клиника Дармштадта, г. Дармштадт, Германия \\ ${ }^{3} \mathrm{OOO} \ll$ «ндирект», г. Челябинск, Российская Федерация
}

\begin{abstract}
Решена задача построения аддитивной модели прогнозирования тарифа рынка на сутки вперед. Трендовая составляющая построена на основе авторегрессионной модели уже известных значений тарифа рынка на сутки вперед и внешнего фактора объема потребления электроэнергии по данным Объединенной энергосистемы (ОЭС) Урала Оптового рынка электрической энергии и мощности (ОРЭМ) России за 20092018 гг. На основе построения автокорреляционной функции выявлено три сезонных составляющих во временном ряду часовых значений тарифа рынка на сутки вперед: годовая (8760 значений), недельная (168 значений), суточная (24 значения). Построена гармоническая модель каждой составляющей. Итоговая аддитивная модель построена с учетом специфики рынка электроэнергетики и процесса формирования тарифа рынка на сутки вперед и балансирующего рынка. Практическая значимость разработанной аддитивной модели заключается в адекватной точности с известными моделями прогнозирования тарифа рынка на сутки вперед ОЭС Урала. Использование предложенной модели позволит субъектам электроэнергетики за счет обеспечение высокой точности прогнозирования избежать штрафных санкций балансирующего рынка.

Ключевые слова: моделирование; прогнозирование; авторегрессия; аддитивная модель; электроэнергетика; энергетический рынок.
\end{abstract}

\section{Литература}

1. Garcia, R.C. Forecasting Model to Predict Day-Ahead Electricity Prices / R.C. Garcia // IEEE Transactions on Power Systems. - 2005. - V. 20, № 2. - P. 867-874.

2. Мохов, В.Г. Построение трендовой составляющей аддитивной модели долгосрочного прогнозирования Оптового рынка электрической энергии и мощности России на примере Объединенной энергосистемы Урала / В.Г. Мохов, Т.С. Демьяненко // Вестник ЮУрГУ. Серия: Экономика и менеджмент. - 2018. - Т. 12, № 2. - С. 80-87.

3. Taylor, J.W. Short-Term Load Forecasting Methods: an Evaluation Based on European Data / J.W. Taylor, P.E. McSharry // IEEE Transactions on Power Systems. - 2008. - V. 22. P. 2213-2219.

4. Taylor, J.W. Short-Term Electricity Demand Forecasting Using Double Seasonal Exponential Smoothing / J.W. Taylor // Journal of Operational Research Society. - 2003. - V. 54. P. 799-805. 
5. Perez, M. Time Series Analysis with Matlab. ARIMA and ARIMAX Models/ M. Perez.Scotts Valley: CreateSpace Independent Publishing Platform, 2016.

Елена Александровна Лясковская, доктор экономических наук, профессор, кафедра «Прикладная экономика», Южно-Уральский государственный университет (г. Челябинск, Российская Федерация), liaskovskaiaea@susu.ru.

Полина Константиновна Заржитская-Тирлинг, доктор естественных наук, отделение кардиологии клиники Дармштадта (г. Дармштадт, Германия), zarjitskayathierling@mail.klinikum-darmstadt.de.

Ольга Александровна Дмитрина, ООО «Индирект», (г. Челябинск, Российская Федерация), dmitrina.oa@mail.ru.

Поступила в редакцию 6 марта 2020 г. 